\title{
EDITORIAL
}

\section{Biological markers and psychosis ${ }^{1}$}

There is consistent evidence from family, twin and adoption studies that schizophrenia (Gottesman \& Shields, 1982) and the major affective disorders (Reich et al. 1982) receive an important genetic contribution to their aetiology. Given that there is this contribution, there must exist some mediating biological processes which constitute the pathway from abnormal genes to abnormal behaviour. The search for biological markers is the search for signposts on this pathway.

As Penrose (1971) has pointed out, psychiatric disorders present peculiar problems for genetic analysis in that they are not characters which 'segregate and are unequivocally recognisable in different surroundings'. Syndromes defined by clinical signs and symptoms, what Gottesman \& Shields (1972) have called 'exophenotypes', may possibly be refined down to more manageable characters if biological markers or 'endophenotypes', lying a step nearer the primary gene product, can be discovered. A nice demonstration of the utility of various kinds of phenotypes in distinguishing between genotypes was given by Penrose (1952). He showed that measuring head size or hair reflectancy (as an indicator of blondness) on normal children and those with phenylketonuria provided overlapping distributions. IQ provided better separation but, again, with two distributions overlapping. However, when phenylalanine levels in the blood were measured the two groups were clearly and widely separated, with the means 13 standard deviations apart. Thus a character which is very near to the primary gene product provides the most unequivocal discrimination and, although the mode of transmission of manic-depressive psychosis or schizophrenia is likely to prove much more complex than this simple autosomal recessive example, the model remains a valid one for psychiatry.

The list of potential candidates for a schizophrenic or manic-depressive endophenotype is large (Nurnberger \& Gershon, 1982; Gottesman \& Shields, 1982). The search has ranged widely over biochemical, endocrinological, and neurophysiological territory. In the absence of any clear-cut lead, what has tended to happen is that whenever a new discovery is made or some new technique evolved in an area that might feasibly be related to the aetiology of psychosis, then it is soon applied in clinical studies. In the majority of cases confusion, contradiction, and failure of replication have been the result. Two possible exceptions are the studies of the dexamethasone suppression test and of platelet monoamine oxidase. In these areas there has been enough consistency at least to suggest that the results are indicators of pathophysiological pathways and not merely the signposts of temporarily fashionable blind alleys. As such, a brief consideration of their relationship to the genetics of psychosis is merited and is of some heuristic value.

The dexamethasone suppression test (DST) has recently been extensively studied in affective disorder (Carroll, 1982), and failure of suppression of blood cortisol levels has been found consistently in $50 \%$ or more of patients with an endogenous pattern of illness. Although there is no excess of non-suppressors among psychiatric patients with other conditions, non-suppression occurs among healthy controls in whom the rate in some recent studies has been more than $10 \%$ (Coppen et al. 1983; Hällström et al. 1983). How good then is the test as a means of defining a group of endogenous depressives? If the proportion of non-suppressors among endogenous depressives (i.e. the sensitivity) is $50 \%$ and the proportion among non-depressives is $10 \%$ (i.e. the specificity is $90 \%$ ) then on a psychiatric ward where the prevalence of endogenous depression is, say, $30 \%$ Bayes' theorem allows us to calculate that the probability that an individual is suffering from endogenous depression, given that he or she has an abnormal test result, is $68 \%$. However,

\footnotetext{
' Address for correspondence: Dr Peter McGuffin, Institute of Psychiatry, De Crespigny Park, Denmark Hill, London SE5 8AF.
} 
applying the same method in a population where the prevalence of endogenous depression is, say, $1 \%$, the probability that an individual has the disorder, given that his or her DST is abnormal, is $5 \%$. Thus the discriminatory power of the test is modest and far short of Penrose's ideal. There may, of course, be heterogeneity in depression, and one study (Schlesser et al. 1979) suggested that dexamethasone non-suppression was significantly more common in those patients with a familial type of depression than in those with a non-familial form. Unfortunately, subsequent studies (Coppen et al. 1983; Hwu et al. 1981) have failed to replicate this finding. The usefulness of the DST from a genetic viewpoint is also limited by the fact that non-suppressors usually revert to normal on recovery from depression and, furthermore, suppressor/non-suppressor status does not remain consistent across subsequent episodes of depression (Coryell \& Schlesser, 1983).

Monoamine oxidase (MAO) is a mitochondrial enzyme involved in the degradation of indole and catecholamines, and appears to exist in two forms which can be distinguished by their preferred substrates. The A type is found in human fibroblasts, while platelets contain B type which is also the form primarily found in the human brain. Platelet MAO activity has been the subject of intense interest in psychiatric research ever since Wyatt et al. (1973) suggested that low activity may serve as a 'genetic marker' of vulnerability to schizophrenia. Since then, there have been many published studies on the subject, the majority of which (but by no means all) have been in agreement with the original findings (Wyatt et al. 1979). However, interest in this potential marker has also spread into work on other conditions and low MAO activity has been associated with bipolar affective illness (Murphy \& Weiss, 1972; Leckman et al. 1977), with alcoholism (Major \& Murphy, 1978; Sullivan et al. 1979), as well as with high scores on Zuckerman's (1974) sensation-seeking personality scale and with having a family history of psychiatric disorder (Buchsbaum et al. 1976; Haier et al. 1980). Studies of platelet MAO in normal families (Pandey et al. 1979) and twins (Nies et al. 1973) strongly suggest that the level of activity is under genetic control. Furthermore, studies in twins discordant for schizophrenia (Wyatt et al. 1973; Reveley et al. 1983) have shown a high correlation for low activity between the schizophrenic probands and their well (and therefore unmedicated) co-twins, suggesting that low platelet MAO cannot be completely explained as an effect of drug treatment. However, the genetic interpretation of the findings is made difficult by the fact that the mode of transmission of platelet MAO is itself unclear. Rice et al. (1982) have recently performed a statistical analysis of the distribution of platelet MAO activity in a large sample of college students. They found that, even when a scale transformation was used to remove skewness, a mixture of three distributions was required to describe the data: such findings suggest single major locus inheritance. A subsequent segregation analysis of family data (Rice et al. 1984) supported this conclusion. Interestingly, both analyses, based on quite separate samples from different laboratories, suggest that the less common allele (with a gene frequency of at most $25 \%$ ) is the one coding for high MAO activity. If this is correct, then the vast majority of the population, over $90 \%$, carry at least one 'low-MAO' gene, with more than half possessing it in double dose. Clearly, this would be at odds with any suggestion that an MAO gene has a specific relationship with a disorder such as schizophrenia, where the lifetime risk is around $0.86 \%$ (Gottesman \& Shields, 1982).

It is apparent, then, that despite a reasonable consistency across studies neither platelet MAO nor the dexamethasone suppression test provides ideal biological markers from the point of view of genetic research. What, then, are the desirable properties of an endophenotype? Reider \& Gershon (1978) have suggested that: (1) a useful biological marker should be associated with an increased risk of psychiatric illness. (However, the character need not always be more common among a group of patients with a psychiatric syndrome since there may be biological heterogeneity.) (2) The character must be heritable, and therefore not a secondary effect of the illness or of treatment for the illness. (3) The character should preferably be a 'trait marker' (like MAO) rather than a 'state marker' (such as the DST) which is no longer observable in the patient on recovery. This last point is particularly relevant to genetic research, since markers which are not state dependent can be studied in both the well and the ill relatives of patients. Indeed, for biological psychiatry in general the potential benefits of concentrating on pairs of relatives (Reider \& Gershon, 1978) or on multiple classes of relatives (Cloninger et al. 1981) are large and are only just beginning to be exploited. One 
interesting recent example is the study of Wright et al. (1984), which demonstrated decreased $\beta$-adrenoreceptors on lymphoblastoid cells in the ill members of three families affected by manicdepressive psychosis, but not among healthy relatives. In two other families the finding was absent in both ill and healthy individuals. Since the abnormality was detected in cultured cells which had been serially passaged over many cell generations, the defect could be presumed to be genetically coded. The great advantage of this study having been performed in families is that apparent heterogeneity was present which would not have been detectable with the more common research paradigm of comparing a group of unrelated patients and controls.

What is the place of genetic markers in present research? This term has often been used somewhat loosely in the psychiatric literature, but it is best reserved for a particular subset of biological markers which have simple Mendelian modes of inheritance and which are polymorphic, i.e. there are two or more alleles with a gene frequency of at least $1 \%$ (Giblett, 1969). Genetic markers can by various methods (McKusick \& Ruddle, 1977; McKusick, 1983) be assigned to specific chromosomal locations, and the filling-in of the human gene map has been one of the most remarkable areas of recent progress in human genetics. So far, there have been 317 genes assigned to human chromosomes and of these 73 are polymorphic (American Journal of Human Genetics, 1983). Even so, it is still not practicable to cover more than a small proportion of the human genome in genetic linkage studies concerned with human diseases, and it has been calculated that several hundred more marker loci are needed to span the human genome (Lange \& Boehnke, 1982). New techniques using recombinant DNA promise to provide many new markers which will perhaps be sufficient for this task (Housman \& Gusella, 1981). However, problems for the analysis of linkage data remain formidable for disorders such as manic-depressive illness and schizophrenia where the modes of inheritance are unknown (McGuffin et al. 1983; Goldin et al. 1983). Thus, for the present, there is much to be said for concentrating research energies on the quest for other forms of inherited biological characteristics which have a reasonable a priori chance of being involved in the aetiology of mental disorder (Vogel \& Propping, 1981). Two important guiding principles are: first, that the potential endophenotype must be carefully studied, not just in patients, but in their affected and unaffected relatives; and, secondly, that the genetics of the marker trait itself must be properly elucidated (Nicol \& Gottesman, 1983).

PETER McGUFFIN

\section{REFERENCES}

American Journal of Human Genetics (1983). The human gene map; 35, $134-156$.

Buchsbaum, M. S., Coursey, R. D. \& Murphy, D. L. (1976). The biochemical high-risk paradigm: behavioral and familial correlates of low platelet monoamine oxidase activity. Science 194, 339-341.

Carroll, B. J. (1982). The dexamethasone suppression test for melancholia. British Journal of Psychiatry 140, 292-304.

Cloninger, C. R., Lewis, C., Rice, J. \& Reich, T. (1981). Strategies for resolution of biological and cultural inheritance. In Genetic Research Strategies in Psychobiology and Psychiatry (ed. E. S. Gershon, S. Matthysse, X. O. Breakfield and R. D. Ciaranello), pp. 319-332. Boxwood: Pacific Grove, California.

Coppen, A., Abou-Saleh, M., Milln, P., Metcalfe, M., Harwood, J. \& Bailey, J. (1983). Dexamethasone suppression test in depression and other psychiatric illness. British Journal of Psychiatry 142, 498-504.

Coryell, W. \& Schlesser, M. A. (1983). Dexamethasone suppression test response in major depression : stability across hospitalizations. Psychiatry Research 8, 179-189.

Giblett, E. R. (1969). Genetic Markers in Human Blood. Blackwell: Oxford.

Goldin, L. R., Gershon, E. S., Targum, S. D., Sparkes, R. S. \& McGinniss, M. (1983). Segregation and linkage analyses in families of patients with bipolar and schizoaffective mood disorders. American Journal of Human Genetics 35, 274-288.
Gottesman, I. I. \& Shields, J. (1972). Schizophrenia and Genetics: A Twin Study Vantage Point. Academic Press: London.

Gottesman, I. I. \& Shields, J. (1982). Schizophrenia, The Epigenetic Puzzle. Cambridge University Press: Cambridge.

Haier, R. J., Buchsbaum, M.S., Murphy, D. L., Gottesman, I. I. \& Coursey, R. D. (1980). Psychiatric vulnerability, monoamine oxidase and the average evoked potential. Archives of General Psychiatry 35, 1198-1202.

Hällström, T., Samuelsson, S., Balldin, J., Wålinder, J., Bengtsson, C., Nyström, E., Andersen, B., Lindstedt, G. \& Lundberg, P. A. (1983). Abnormal dexamethasone suppression test in normal females. British Journal of Psychiatry 142, 489-497.

Housman, D. \& Gusella, J. (1981). Use of recombinant DNA techniques for linkage studies of genetically based neurological disorders. In Genetic Research Strategies in Psychobiology and Psychiatry (ed. E. S. Gershon, S. Matthysse, X. O. Breakfield and R. D. Ciaranello), pp. 17-24. Boxwood: Pacific Grove, California.

Hwu, H., Rudorfer, M. V. \& Clayton, P. J. (1981). Dexamethasone suppression test and subtypes of depression. (Letter to editor.) Archives of General Psychiatry 38, 363.

Lange, K. \& Boehnke, M. (1982). How many polymorphic marker genes will it take to span the human genome? American Journal of Human Genetics 34, 842-845.

Leckman, J. F., Gershon, E. S., Nichols, A. J. \& Murphy, D. C. (1977). Reduced MAO activity in first degree relatives of individuals with bipolar affective disorders. Archives of General Psychiatry 34, 601-608. 
Major, L. F. \& Murphy, D. L. (1978). Platelet and plasma amine oxidase activity in alcoholic individuals. British Journal of Psychiatry 132, 548-553.

McGuffin, P., Festenstein, H. \& Murray, R. (1983). A family study of HLA antigens and other genetic markers in schizophrenia. Psychological Medicine 13, 31-43.

McKusick, V. A. (1983). Mendelian Inheritance in Man (6th edn). Johns Hopkins University Press: Baltimore.

McKusick, V. A. \& Ruddle, F. H. (1977). The status of the gene map of the human chromosomes. Science 196, 390-405.

Murphy, D. L. \& Weiss, R. (1972). Reduced monoamine oxidase activity in blood platelets from bipolar depressed patients. American Journal of Psychiatry 128, 35-40.

Nicol, S. E. \& Gottesman, I. I. (1983). Clues to the genetics and neurobiology of schizophrenia. American Scientist 71, 398-404.

Nies, A., Robinson, D. S., Lamborn, K. R. \& Lampert, R. P. (1973) Genetic control of platelet and plasma monoamine oxidase activity. Archives of General Psychiatry 28, 834-838

Nurnberger, J. I. \& Gershon, E. S. (1982). Genetics. In Handbook of Affective Disorders (ed. E. S. Paykel), pp. 126-145. Churchill Livingstone: Edinburgh.

Pandey, E. W., Dorus, E., Shaughnessy, R. \& Davis, J. M. (1979). Genetic control of platelet monoamine oxidase activity: studies on normal families. Life Sciences 25, 1173-1178.

Penrose, L. S. (1952). Measurement of pleiotropic effects in phenylketonuria. Annals of Eugenics 18, 120-124.

Penrose, L. S. (1971). Psychiatric genetics (editorial). Psychological Medicine 1, 265-266.

Reich, T., Cloninger, C. R., Suarez, B. \& Rice, J. (1982). Genetics of the affective disorders. In Handbook of Psychiatry: Psychoses of Unknown Aetiology (ed. J. K. Wing and L. Wing), pp. 147-159. Cambridge University Press: Cambridge.

Reider, R. O. \& Gershon, E. S. (1978). Genetic strategies in biological psychiatry. Archives of General Psychiatry 35, 866-873.

Reveley, M. A., Reveley, A. M., Clifford, C. A. \& Murray, R. M.
(1983). Genetics of platelet MAO activity in discordant schizophrenic and normal twins. British Journal of Psychiatry 142, 560565.

Rice, J., McGuffin, P. \& Shaskan, E. (1982). A commingling analysis of platelet monoamine oxidase activity. Psychiatry Research 7 323-335.

Rice, J., McGuffin, P., Goldin, L. R., Shaskan, E. G. \& Gershon, E. S. (1984). Platelet monoamine oxidase activity: evidence for a single major locus. American Journal of Human Genetics 36, 36-43.

Schlesser, M. A., Winokur, G. \& Sherman, B. M. (1979). Genetic subtypes of unipolar primary depressive illness distinguished by hypothalamic-pituitary-adrenal axis activity. Lancet i, 739-740.

Sullivan, J. L., Cavenar, J. P., Maltbie, R. A., Lisler, P. \& Zung, W. W. K. (1979). Familial biochemical and clinical correlates of alcoholics with low platelet monoamine oxidase activity. Biological Psychiatry 14, 385-392.

Vogel, F. \& Propping, P. (1981). The electroencephalogram (EEG) as a research tool in human behavior genetics. In Genetic Research Strategies in Psychobiology and Psychiatry (ed. E. S. Gershon, S. Matthysse, X. O. Breakfield and R. D. Ciaranello), pp. 269-282. Boxwood: Pacific Grove, California.

Wright, A. F., Crichton, D. N., Loudon, J. B., Morten, J. E. N. \& Steel, C. M. (1984). $\beta$-adrenoceptor binding defects in cell lines from families with manic depressive disorder. Annals of Human Genetics (in the press).

Wyatt, R. J., Murphy, D. L., Belmaker, R., Cohen, S., Donnelly, C. H. \& Pollin, W. (1973). Reduced monoamine oxidase activity in platelets: a possible genetic marker for vulnerability to schizophrenia. Science 179, 916-918.

Wyatt, R. J., Potkin, S. G. \& Murphy, D. L. (1979). Platelet monoamine oxidase activity in schizophrenia : a review of the data. American Journal of Psychiatry 136, 377-382.

Zuckerman, M. (1974). The sensation seeking motive. In Progress in Experimental Personality Research Vol. 7 (ed. B. Maher), pp. 79-148. Academic Press: New York. 